\title{
FAKTOR YANG MEMPENGARUHI LAMA PENYEMBUHAN GANGGREN PASIEN DIABETES MELLITUS DI KLINIK ALFACARE
}

\author{
Pauzan Efendi $^{1}$, Kosma Heryati ${ }^{1}$, Erni Buston ${ }^{1}$ \\ ${ }^{1}$ Jurusan Keperawatan, Poltekkes Kemenkes Bengkulu, Jalan Indragiri Nomor 03 \\ Padang Harapan, Bengkulu, 38225. \\ Email : ernibuston87@gmail.com
}

\begin{abstract}
Background: The number of people affected by diabetes in Indonesia increased with growth of $152 \%$ or from 8.426 million people in 2000 to 21.257 million people in 2030. Many factors contribute to the long process of healing diabetic ulcers which came from wound care, infection control, vascularity, age, nutrition, disease complications, etc. Objective: Knowing Factors Affecting Wound Healing gangrene in Patients with Diabetes Mellitus. Method: Type of research is descriptive analytic design used cross sectional. The samples in this study are 44 patients with Diabetes Mellitus who have gangrene wound, with simple random sampling technique. Data analysis was performed using univariate and bivariate using Wilcoxon test. Results: Research has been conducted in July to November 2019. 44 respondents found the factors that affect the long wound gangrene in diabetic patients include age factor $(\mathrm{p}=0.003$ $<0.05)$, factor-stage lesions $(\mathrm{p}=0.036<0.05)$, and the value of GDS $(\mathrm{p}=0.001<0.05)$. Suggestion: The health professionals and researchers to be able develop and examine more deeply related factors that can impede the gangrene, also can provide patient education regarding related gangrene wound so as to create a holistic service.
\end{abstract}

Keywords : Gangrene, Diabetes Mellitus, Factors Influencing, Wound Healing

\begin{abstract}
Abstrak
Latar belakang: Indonesia menduduki peringkat keempat terbesar penyakit diabetes dari 8.426.000 orang pada tahun 2000 menjadi 21.257.000 orang di tahun 2030. Sepertiga dari kasus Diabetes Melitus mempunyai masalah dengan luka pada kakinya. Banyak faktor yang berperan terhadap lama proses penyembuhan luka di antaranya berasal dari perawatan luka, pengendalian infeksi, vaskularisasi, usia, nutrisi, penyakit komplikasi, dsb. Tujuan: Mengetahui Faktor yang Mempengaruhi Lama Penyembuhan Luka Ganggren pada Pasien Diabetes Mellitus. Metode: Jenis penelitian adalah Deskriptif Analitik, desain penelitian yang digunakan cross sectional. Sampel penelitian ini adalah 44 pasien Diabetes Mellitus yang mempunyai luka ganggren. Teknik pengambilan sampel yaitu simple random sampling. Pengumpulan data dengan menggunakan lembar pengkajian. Analisis data dilakukan dengan uji wilcoxon. Hasil: Penelitian dilaksanakan pada Juli - November 2019. Didapatkan faktor-faktor yang mempengaruhi lama luka ganggren pada pasien DM diantaranya umur $(\mathrm{p}=0.003<0.05)$, stadium luka $(\mathrm{p}=0.036<0.05)$, nilai pemeriksaan GDS $(p=0.001<0.05)$, dan faktor pengaruh berat luka $(p=0.012<0.05)$. Saran: Diharapakan tenaga kesehatan dan peneliti lain dapat mengembangkan dan mengkaji lebih dalam terkait faktor yang menghambat lama penyembuhan luka ganggren dan memberikan edukasi kepada pasien mengenai perawatan luka ganggren sehingga terciptanya pelayanan yang holistik.
\end{abstract}

Kata Kunci : Luka ganggren, Diabetes Mellitus, Faktor yang Berpengaruh, Lama Penyembuhan 
Mahakam Nursing Journal Vol 2, No. 7, Mei 2020 : 286 - 297

\section{PENDAHULUAN}

Diabetes mellitus merupakan sekelompok kelainan heterogen yang ditandai oleh kenaikan kadar glukosa dalam darah atau hiperglikemia. Glukosa secara normal bersirkulasi dalam jumlah tertentu dalam darah (Smeltzer, 2008).

Menurut American Diabetes Association (ADA) (2005), Diabetes Melitus (DM) merupakan suatu kelompok penyakit metabolik dengan karakteristik hiperglikemia yang terjadi karena kelainan sekresi insulin, kerja insulin atau kedua-duanya. Hiperglikemia kronik pada diabetes berhubungan dengan kerusakan jangka panjang, disfungsi atau kegagalan beberapa organ tubuh, terutama mata, ginjal, saraf, jantung, dan pembuluh darah (Soegondo, 2013).

Kenaikan jumlah penduduk dunia yang terkena penyakit diabetes atau kencing manis semakin mengkhawatirkan. Jumlah penduduk dunia yang menderita diabetes sudah mencapai 171.230.000 orang dan pada tahun 2030 diperkirakan jumlah penderita diabetes di dunia akan mencapai jumlah 366.210 .100 orang atau naik sebesar $114 \%$ dalam kurun waktu 30 tahun. Indonesia menduduki peringkat keempat terbesar dengan pertumbuhan sebesar $152 \%$ atau dari 8.426 .000 orang pada tahun 2000 menjadi 21.257.000 orang di tahun 2030 (WHO, 2000).

Menurut laporan United Kingdom Prospective Diabetes Study (UKPDS) Komplikasi kronis paling utama dari Diabetes Melitus adalah penyakit Kardiovaskuler dan Stroke, Diabetic foot ulcer, Retinopati, serta NefropatiDiabetic (King, Peacock, \& Donnelly, 1999)

Berdasarkan angka prevalensi penderita Diabetes Melitus, di Indonesia mempunyai resiko sekitar $15 \%$ terjadinya ulkus kaki diabetik, komplikasi amputasi sebanyak 30\%, angka mortali$\operatorname{tas} 32 \%$ dan ulkus diabetik merupakan sebab perawatan rumah sakit yang terbanyak sebesar $80 \%$ untuk Diabetes Melitus. Amputasi tungkai bawah paling banyak karena luka kaki diabetes, jumlah penderita Diabetes Melitus dengan luka kaki terus meningkat dan resiko 15-16 kali lebih besar untuk amputasi. Deteksi dini dan penanganan yang tepat pada luka dapat mencegah 85 $\%$ amputasi. Observasi yang dilihat selama ini bahwa penyakit Diabetes Melitus terus mengalami peningkatan jumlah penderita dari tahun ketahun, 
kemudian pada sebagian besar kasus

Diabetes Melitus disertai dengan timbulnya luka pada kaki. Kebanyakan pada penderita Diabetes Melitus yang mengalami luka jika tidak dilakukan perawatan luka dengan baik dan benar, sehingga meningkatkan kasus amputasi bahkan kematian (Adi, 2010).

Banyak faktor yang berperan terhadap lama proses penyembuhan ulkus diabetik di antaranya dapat berasal dari perawatan luka, pengendalian infeksi, vaskularisasi, usia, nutrisi, penyakit komplikasi, adanya riwayat merokok, pengobatan, psikologis, dll (Yadi, 2000). Luka diabetik juga dikarakteristikkan sebagai luka kronis yang memiliki waktu penyembuhan lama. Lama waktu penyembuhan luka diabetik disebabkan karena respon inflamasi yang memanjang. Lama waktu penyembuhan luka diabetik dapat mencapai 12-20 minggu. Luka diabetik yang tidak sembuh menjadi faktor resiko infeksi dan peneybab utama dilakukannya amputasi serta kematian (Rahmadiliyani, dkk, 2008).

Sampai saat ini, persoalan kaki diabetik masih kurang dapat perhatian dan kurang di mengerti sehingga masih muncul konsep dasar yang kurang tepat pada pengelolaan kaki diabetik. Aki- batnya banyak penderita yang harus teramputasi kakinya, padahal kaki tersebut masih bisa diselamatkan secara lebih dini, lebih cepat dan lebih baik (Syamsuhidayat R, Jong WD, eds., 2010).

Dari penjelasan di atas, maka dapat disimpulkan bahwa lama penyembuhan luka diabetik dipengaruhi oleh berbagai faktor. Oleh karena itu, untuk lebih mengetahui faktor-faktor yang mempengaruhi lama penyembuhan luka diabetik, maka perlu dilakukan penelitian mengenai hal tersebut.

\section{METODE PENELITIAN}

Jenis penelitian ini adalah Deskriptif Analitik dengan desain yang digunakan adalah cross sectional yaitu penelitian yang mempelajari hubungan antara variabel bebas (faktor resiko) dengan variabel tergantung (faktor efek) dengan melakukan pengukuran sesaat atau secara bersamaan. Populasi pada penelitian ini adalah, seluruh pasien yang menjalani pengobatan di Klinik Perawatan Luka Alfacare Centre Bengkulu.

Pengambilan sampel dalam penelitian ini menggunakan rumus cross sectional dan menggunakan tehnik Sim- 
ple random sampling atau secara acak terhadap seluruh pasien di Klinik Perawatan Luka Alfacare Centre yang mengalami penyakit Diabetes Mellitus yang berjumlah 44 orang.

Pengumpulan data dilakukan dengan menggunakan lembar berisi pengkajian yang akan ditanyakan kepada responden dengan wawancara dan observasi. Lembar pengkajian digunakan untuk mengumpul-kan data seperti nama, umur, jenis kelamin, riwayat peyakit, pengkajian luka, nilai pemeiksaan GDS, dsb.

Analisis data dilakukan secara univariat untuk melihat distrubusi frekuensi masing-masing variabel penelitian, dan analisis bivariat dengan menggunakan uji chi-square pada $\alpha 5 \%$ untuk melihat hubungan variabel independen dengan variabel dependen.

\section{HASIL DAN PEMBAHASAN}

Tabel 1 : Distribusi Frekuensi Faktor yang Mempengaruhi Lama Penyembuhan Luka Ganggren pada Pasien Diabetes Mellitus di Klinik Perawatan Luka Alfacare Centre Bengkulu

\begin{tabular}{cllcc}
\hline No & \multicolumn{1}{l}{ Faktor yang } & Mempengaruhi & F & $\%$ \\
\hline \multirow{2}{*}{ 1. } & \multirow{2}{*}{ Umur } & $>55$ Tahun & 29 & $65.9 \%$ \\
& & $<55$ Tahun & 15 & 34.1 \\
2. & Riwayat & Ada & 31 & $70.5 \%$ \\
& DM & Tidak Ada & 13 & $29.5 \%$ \\
3. & Penyakit & Ada & 21 & $47.7 \%$ \\
& Lain & Tidak Ada & 23 & $52.3 \%$ \\
4. & Stadium & 3 \& 4 & 21 & $47.7 \%$ \\
& Luka & $1 \& 2$ & 23 & $52.3 \%$ \\
5. & Luka & Luka Berat & 24 & $54.5 \%$ \\
& & Luka Ringan & 20 & $45.5 \%$
\end{tabular}

\begin{tabular}{lcccc}
\hline No & \multicolumn{1}{c}{ Faktor yang Mempengaruhi } & F & $\%$ \\
\hline \multirow{2}{*}{ 6. Hari Rawat } & \multirow{2}{*}{ Hadak Normal } & 23 & $75 \%$ \\
& & Normal & 11 & $25 \%$ \\
\hline
\end{tabular}

Data responden selama penelitian seperti yang tersaji pada tabel diatas menunjukkan distribusi frekuensi responden berdasarkan Riwayat DM sebanyak 31 orang $(70.5 \%)$, responden berdasarkan Penyakit Lain sebanyak 21 orang $(47.7 \%)$, responden berdasarkan stadium luka $3 \& 4$ sebanyak 21 orang (47.7\%), responden berdasarkan luka berat sebanyak 24 orang $(54.5 \%)$, dan responden berdasarkan hari rawat tidak normal atau lama penyembuhan luka yang memanjang sebanyak 23 orang $(75 \%)$.

Tabel 2 : Pengaruh Umur Terhadap Lama Penyembuhan Luka Ganggren pada Pasien Diabetes Mellitus di Klinik Perawatan Luka Alfacare Centre Bengkulu Tahun 2019.

\begin{tabular}{|c|c|c|c|c|c|}
\hline \multirow[b]{2}{*}{ Umur } & \multicolumn{2}{|c|}{ Hari Rawat } & \multirow[b]{2}{*}{ Total } & \multirow[b]{2}{*}{ S.E } & \multirow[b]{2}{*}{$\begin{array}{c}P \\
\text { value }\end{array}$} \\
\hline & Normal & $\begin{array}{c}\text { Tidak } \\
\text { Normal }\end{array}$ & & & \\
\hline $\begin{array}{c}\text { Beresiko } \\
(>55)\end{array}$ & 3 & 26 & 29 & & \\
\hline$\%$ & $27.3 \%$ & $78.8 \%$ & $65.9 \%$ & & \\
\hline Tidak & & & & 9.905 & 0.03 \\
\hline $\begin{array}{c}\text { Beresiko } \\
(<55)\end{array}$ & 7 & 8 & 15 & & \\
\hline$\%$ & $21.2 \%$ & $72.7 \%$ & $34.1 \%$ & & \\
\hline
\end{tabular}

Tabel diatas menunjukkan sebanyak 65.9\% responden berada pada umur beresiko ( $>55$ tahun). Persentase hari rawat tidak normal pada responden beresiko lebih besar yaitu $78.8 \%$ daripada 
persentase hari rawat tidak normal pada responden tidak beresiko yaitu $72.7 \%$.

Hasil uji statistik nilai $p=0.003<0.05$ dengan nilai $\mathrm{SE}=9.905$ dan dapat disimpulkan adanya korelasi antara umur dengan lama penyembuhan luka, sehingga dapat ditarik kesimpulan yaitu pada pasien dengan umur beresiko lebih berpengaruh terhadap lama penyembuhan luka ganggren pada pasien Diabetes Mellitus.

Tabel 3 : Pengaruh Riwayat Penyakit Terhadap Lama Penyembuhan Luka Ganggren pada Pasien Diabetes Mellitus di Klinik Perawatan Luka Alfacare Centre Bengkulu Tahun 2019.

\begin{tabular}{|c|c|c|c|c|c|}
\hline \multirow{2}{*}{$\begin{array}{c}\text { Riwayat } \\
\text { Penyakit } \\
\text { Lain }\end{array}$} & \multicolumn{2}{|c|}{ Hari Rawat } & \multirow[b]{2}{*}{ Total } & \multirow[b]{2}{*}{ S.E } & \multirow[b]{2}{*}{$\begin{array}{c}P \\
\text { value }\end{array}$} \\
\hline & Normal & $\begin{array}{c}\text { Tidak } \\
\text { Normal }\end{array}$ & & & \\
\hline Ada & 4 & 17 & 21 & & \\
\hline$\%$ & $36.4 \%$ & $51.5 \%$ & $47.7 \%$ & & \\
\hline $\begin{array}{c}\text { Tidak } \\
\text { Ada }\end{array}$ & 7 & 16 & 23 & 1.859 & 0.49 \\
\hline$\%$ & $48.5 \%$ & $63.6 \%$ & $52.3 \%$ & & \\
\hline
\end{tabular}

Berdasarkan tabel diatas, persentase jumlah responden dengan riwayat penyakit lain adalah $47.7 \%$ dengan hari rawat tidak normal sebesar $51.5 \%$, dan persentasi jumlah responden yang tidak mempunyai riwayat penyakit lain lebih besar yaitu $52.3 \%$, dengan hari rawat tidak normal juga lebih besar yaitu $63.6 \%$. Hal ini menunjukkan tidak adanya korelasi antara ada/tidaknya riwayat penyakit lain dengan hari rawat atau lamanya penyembuhan luka, dan juga dapat dibuktikan dengan hasil uji statistik nilai $\mathrm{p}=0.494>0.05$ sehingga dapat disimpulkan, rendahnya pengaruh riwayat lain terhadap lama penyembuhan luka ganggren pada pasien Diabetes Mellitus dengan S.E = 1.859 .

Tabel 4 : Pengaruh Stadium Luka Terhadap Lama Penyembuhan Luka Ganggren pada Pasien Diabetes Mellitus di Klinik Perawatan Luka Alfacare Centre Bengkulu Tahun 2019.

\begin{tabular}{|c|c|c|c|c|c|}
\hline \multirow{2}{*}{$\begin{array}{c}\text { Stadium } \\
\text { Luka }\end{array}$} & \multicolumn{2}{|c|}{ Hari Rawat } & \multirow{2}{*}{ Total } & \multirow[b]{2}{*}{ S.E } & \multirow[b]{2}{*}{$\begin{array}{c}P \\
\text { value }\end{array}$} \\
\hline & Normal & $\begin{array}{c}\text { Tidak } \\
\text { Normal }\end{array}$ & & & \\
\hline \multirow{2}{*}{$3 \& 4$} & 2 & 19 & 21 & \multirow{4}{*}{6.107} & \multirow{4}{*}{0.036} \\
\hline & $18.2 \%$ & $57.6 \%$ & $47.7 \%$ & & \\
\hline $1 \& 2$ & 9 & 14 & 23 & & \\
\hline$\%$ & $21.2 \%$ & $72.7 \%$ & $34.1 \%$ & & \\
\hline
\end{tabular}

Menurut data diatas, persentase jumlah responden dengan stadium luka $1 \& 2$ lebih besar yaitu 52.3\% dengan persen hari rawat tidak normal $42.4 \%$. Namun pada responden dengan sadium luka $3 \& 4$, persentase hari rawat tidak normal lebih besar yaitu $57.6 \%$ dengan nilai $\mathrm{p}=0.036<0.05$ dan $\mathrm{S} . \mathrm{E}=6.107$. Sehingga dapat disimpulkan bahwa adanya korelasi antara stadium luka dan lama penyembuhan luka, dengan semakin besarnya stadium luka maka akan berpengaruh dengan lama penyembuhan luka ganggren pada pasien Diabetes Mellitus. 
Tabel 5 : Pengaruh Nilai GDS Terhadap Lama Penyembuhan Luka Ganggren pada Pasien Diabetes Mellitus di Klinik Perawatan Luka Alfacare Centre Bengkulu Tahun 2019.

\begin{tabular}{|c|c|c|c|c|c|}
\hline \multirow[b]{2}{*}{$\begin{array}{l}\text { Nilai } \\
\text { GDS }\end{array}$} & \multicolumn{2}{|c|}{ Hari Rawat } & \multirow{2}{*}{ Total } & \multirow[b]{2}{*}{ S.E } & \multirow{2}{*}{$\begin{array}{c}P \\
\text { value }\end{array}$} \\
\hline & Normal & $\begin{array}{c}\text { Tidak } \\
\text { Normal }\end{array}$ & & & \\
\hline $\begin{array}{l}\text { Tidak } \\
\text { Normal }\end{array}$ & 2 & 25 & 27 & & \\
\hline$\%$ & $18.2 \%$ & $75,8 \%$ & $61,4 \%$ & 14.063 & 0.001 \\
\hline Normal & 9 & 8 & 17 & & \\
\hline$\%$ & $81.8 \%$ & $24.2 \%$ & $38.6 \%$ & & \\
\hline
\end{tabular}

Berdasarkan tabel diatas, persentase jumlah responden dengan nilai GDS tidak normal lebih banyak daripada responden dengan nilai GDS normal, yaitu $61.4 \%$ dengan persentase hari rawat tidak normal sebesar $75.8 \%$. Sedangkan pada responden dengan nilai GDS normal, persentase hari rawat tidak normal justru lebih rendah yaitu $24.2 \%$. Hasil uji statistik didapatkan nilai $\mathrm{p}=0.001<$ 0.05 dan S.E $=14.06$, sehingga dapat disimpulkan bahwa adanya hubungan antara nilai GDS responden terhadap lama penyembuhan luka, dimana semakin tidak normalnya nilai GDS maka berpengaruh terhadap semakin lama penyembuhan luka ganggren pada pasien Diabetes Mellitus.
Tabel 6 : Pengaruh Berat Luka Terhadap Lama Penyembuhan Luka Ganggren pada Pasien Diabetes Mellitus di Klinik Perawatan Luka Alfacare Centre Bengkulu Tahun 2019.

\begin{tabular}{|c|c|c|c|c|c|}
\hline Berat / & \multicolumn{2}{|c|}{ Hari Rawat } & \multirow[b]{2}{*}{ Total } & \multirow[b]{2}{*}{ S.E } & \multirow[b]{2}{*}{$\begin{array}{c}P \\
\text { value }\end{array}$} \\
\hline $\begin{array}{c}\text { Ringan } \\
\text { Luka }\end{array}$ & Normal & $\begin{array}{c}\text { Tidak } \\
\text { Normal }\end{array}$ & & & \\
\hline $\begin{array}{l}\text { Luka } \\
\text { Berat }\end{array}$ & 2 & 22 & 24 & \multirow{4}{*}{9.000} & \multirow{4}{*}{0.012} \\
\hline$\%$ & $18.2 \%$ & $66.7 \%$ & $54.5 \%$ & & \\
\hline $\begin{array}{l}\text { Luka } \\
\text { Ringan }\end{array}$ & 9 & 11 & 20 & & \\
\hline$\%$ & $81.8 \%$ & $33.3 \%$ & $45.5 \%$ & & \\
\hline
\end{tabular}

Menurut tabel diatas, persentase jumlah responden dengan luka berat lebih banyak yaitu 54.5\%, dengan persentase hari rawat tidak normal sebesar 66.7\%. Sedangkan pada respnden dengan luka ringan, persentase hari rawat normal lebih besar yaitu $81.8 \%$. Hasil uji statistik didapatkan nilai $\mathrm{p}=$ $0.012<0,05$ dan S.E $=9.000$. Sehingga dapat ditarik kesimpulan adanya hubungan antara berat luka terhadap lama penyembuhan, dimana semakin berat luka, maka akan berpengaruh terhadap semakin lama penyembuhan luka ganggren pada pasien Diabetes Mellitus.

\section{Gambaran Karakteristik Responden}

Dari hasil penelitian didapatkan bahwa total seluruh reponden berjumlah 44 orang, dimana responden dengan umur $>55$ tahun berjumlah 29 orang. Distribusi frekuensi pada seluruh re- 
sponden didapatkan sebanyak 31 orang mempunyai riwayat DM, 21 orang mempunyai riwayat penyakit lain, responden dengan stadium luka $3 \& 4$ sebanyak 21 orang, responden dengan luka berat 24 orang, dan responden dengan hari rawat tidak normal berjumlah 23 orang.

Faktor-faktor yang mempengaruhi lama penyembuhan luka ganggren pada pasien Diabetes Mellitus.

Berdasarkan hasil penelitian pada pasien diabetes mellitus di Klinik Perawatan Luka Alfacare Centre Bengkulu, didapatkan faktor-faktor yang berpengaruh pada lama penyembuhan luka ganggren yaitu umur, stadium luka, nilai pemeriksaan GDS, dan tingkat berat atau ringannya luka. Sedangkan, untuk faktor yang tidak berpengaruh terhadap lama penyembuhan luka ganggren pada pasien dengan DM yaitu riwayat penyakin lain yang di derita oleh pasien.

\section{a. Umur}

Pada faktor umur, lebih dari setengah jumlah responden (65.9\%) berusia $>55$ tahun dan masuk kedalam kategori umur beresiko, dimana hal ini sejalan dengan penelitian Nugroho (2008) yang mengatakan bahwa pada kelompok lan- sia memiliki resiko lebih tinggi menderita gamggren.

Kelompok umur beresiko ( $>55$ tahun) mempunyai persentase hari rawat atau lama penyembuhan luka tidak normal lebih besar yaitu 78.8\%. Sedangkan, pada responden dengan umur tidak beresiko ( $<55$ tahun) didapatkan persentase hari rawat lebih rendah dari kelompok responden yang berusia $>55$ tahun, yaitu $72.7 \%$. Hasil uji statistik didapatkan nilai $\mathrm{p}=0.003$ lebih kecil dari $\alpha=0.05$ dan S.E $=9.905$, dapat disimpulkan bahwa semakin beresiko umur psaien dengan Diabetes Mellitus, maka akan berpengaruh terhadap semakin lama penyembuhan luka ganggren.

Hal ini sesuai dengan penelitian Hastuti (2008) bahwa sebagian besar responden mengalami perlambatan pada penyembuhan luka ganggre pada kelompok rentang usia 55-59 tahun karena pada usia ini fungsi tubuh secara fisiologis menurun. Lebih lanjut, hasil penelitian ini sejalan dengan hasil penelitian yang dilakukan oleh Lestari (2012) yaitu sebanyak $72.7 \%$ penderita ganggren yang memiliki hari rawat lebih lama terhadap luka adalah kelompok usia lansia karena jumlah elastin kulit yang menurun dan proses re- 
generasi kolagen yangberkurang akibat bertambahnya usia.

Organisasi WHO berpendapat bahwa individu yang berusia setelah 30 tahun akan mengalami kenaikan kadar glukosa darah 1-2 mg/dl pada saat puasa dan naik 5.6-13 $\mathrm{mg} / \mathrm{dl}$ pada 2 jam setelah makan sehingga dapat menimbun insulin di sel-sel tubuh yang dapat mengurangi efektifitas zat-zat seperti protein dan mineral lainnya dalam proses penyembuhan luka ganggren (ADA, 2010).

Penuaan menyebabkan sel kulit berkurang keelastisannya diakibatkan dari menurunnya cairan vaskularisasu di kulit dan berkurangnya kelenjar lemak yang semakin mengurangi kemampuan regenerasi sel ketika luka akan dan mulai menutup sehingga dapat memperlambat penyembuhan luka (Nugroho, 2008).

\section{b. Stadium Luka}

Hasil uji statistik pada faktor stadium luka didapatkan nilai $\mathrm{p}=0.036<$ 0.05 dengan S.E $=$ 6.107. Persentase jumlah responden dengan stadium $1 \& 2$ lebih besar yaitu $52.3 \%$ dengan hari rawat tidak normal $42.4 \%$, dan pada responden dengan stadium luka $3 \& 4$ persentase hari rawat tidak normal lebih besar daripada responden dengan stadi- um luka $1 \& 2$, yaitu $57,6 \%$. Sehingga berdasarkan data diatas dapat diketahui bahwa adanya hubungan antara stadium luka dengan lama penyembuhan luka ganggren.

Semakin tinggi stadium pada luka maka akan semakin lama waktu penyembuhan terhadap luka ganggren pada pasien Diabetes Mellitus. Hal ini sejalan dengan penelitian Arisanti (2013) menyatakan bahwa ganggren yang merupakan luka kronis tidak akan mudah untuk sembuh karena adanya gangguan penyembuhan oleh berbagai faktor baik sistemik dan lokal, dimana stadium luka termasuk pada faktor tersebut.

Dalam penelitian Yunus (2015) yang menyatakan bahwa tingginya penderita ganggren stadium III dan IV dikarenakan masih kurangnya pengetahuan dan perhatian penderita ganggren untuk segera menangani lukanya saat terjadi luka awal. Kebanyakan masyarakat awam lebih membiarkan lukanya tetap terbuka dengan asumsi "luka terbuka akan lebih cepat kering dan kalau luka sudah kering berarti luka sudah sembuh". Luka yang terbuka rentan terhadap gesekan, trauma, bahkan infeksi sehingga menghamat 
proses penyembuhan ganggren dan memperpanjang lama perawatan luka.

\section{c. Pada faktor nilai pemeriksaan GDS}

Pemeriksaan nilai GDS didapatkan persentase sebanyak $61.4 \%$ merupakan responden dengan nilai GDS tidak normal, dimana responden dengan nilai GDS tidak normal mempunyai hari rawat tidak normal lebih besar yaitu 75.8\%. Sedangkan pada pasien dengan nilai GDS normal, hari rawat tidak normal justru lebih rendah yaitu $24.2 \%$. sehingga pasien yang memiliki nilai GDS tidak normal cenderung mempunyai hari rawat tidak normal lebih besar.

Hasil uji statistik didapatkan nilai $\mathrm{p}$ $=0.001<0.05$ dan S.E $=14.06$ yang berarti adanya hubungan antara nilai GDS dengan lamanya penyembuhan luka dimana semakin tinggi nilai pemeriksaan GDS, maka akan semakin lama proses penyembuhan luka pada pasien Diabetes Mellitus.

Hal ini sesuai menurut Noer (2009) dimana pada penderita DM apabila kadar glukosa darah tidak terkendali menyebabkan abnormalitas leukosit sehingga fungsi khemotoksis di lokasi radang terganggu, sehingga bila ada infeksi mikroorganisme akan membutuhkan waktu lebih lama karena infeksi su- kar untuk dimusnahkan oleh sistem phlagositosis-bakterisid intra selluler.

Lebih lanjut, hasil penelitian ini sejalan dengan penelitian yang dilakukan oleh John Lede, dkk (2018) yang menyimpulkan bahwa semakin tinggi kadar gula dalam darah maka semakin tinggi lama proses penyembuhan luka pada diabetes mellitus. Kadar gula darah sangar mempengaruhi proses penyembuhan luka diabetes mellitus.

Penyembuhan luka adalah suatu proses yang kompleks dengan melibatkan banyak sel. Proses penyembuhan luka terdiri dari beberapa fase yaitu fase koagulasi, inflamasi, poliferasi, dan remodeling. Penyembuhan luka juga didefinisikan sebagai suatu proses yang kompleks dan dinamis yang menghasilkan perbaikan terhadap struktur anatomi dan fungsi jaringan (Hess, 2002).

\section{d. Faktor tingkat berat atau rin- gannya luka}

Menurut Arisanti (2013), berat atau ringannya luka berpengaruh pada lama penyembuhan karena adanya gangguan faktor sistemik dan lokal yang terjadi, dimana semakin berat jenis lukanya maka faktor sistemik dan lokal yang mempengaruhi lama penyembuan juga akan meningkat. 
Selain itu, menurut Ismayanti (2007), penyembuhan luka merupakan suatu proses yang kompleks dan dinamis karena merupakan suatu kesatuanbioseluler dan biokimia yang terjadi saling berkesinambungan, dalam proses penyembuhan luka terdapat faktor instrinsik dan ekstrinsik yang mempengaruhi proses tersebut dalah satunya adalah tingkat berat atau ringannya luka.

Hal ini sesuai dengan hasil penelitian dimana pada responden dengan luka berat mempunyai persentase hari rawat tidak normal lebih tinggi yaitu $66.7 \%$, dan hasil uji statistik dimana didapatkan nilai $\mathrm{p}=0.012<0.05$ dan S.E $=9.000$ pada faktor berat $/$ ringannya luka terhadap lama penyembuhan luka ganggren pada pasien Diabetes Mellitus.

\section{e. Riwayat Penyakit Lain}

Dari keempat faktor yang mempengaruhi lama penyembuhan luka, ada satu faktor yang merupakan faktor yang tidak mempengaruhi lama penyembuhan luka, yaitu riwayat penyakit lain yang ada pada pasien DM dengan luka ganggren.

Pada faktor ini hasil uji statistik didapatkan nilai $\mathrm{p}=0.494$ lebih dari $\alpha=0.05$, dapat disimpulkan tidak ada pengaruh yang signifikan antara riwayat penyakit dengan hari rawat. Lebih lanjut data yang didapat pada saat penelitian yaitu, persentase hari rawat tidak normal pada responden yang mempunyai riwayat penyakit lain, lebih rendah dari responden dengan riwayat penyakit lain.

Salah satu riwayat penyakit lain yang berpengaruh terhadap lama penyembuhan luka ganggren adalah hipertensi. Menurut Arisanti (2013), hipertensi merupakan komordibitas penting dalam diabetes, hipertensi dapat menjadi penyulit maupun sebagai faktor prediksi diabetes. Hal ini disebabkan perannya yang sangat penting dalam proses perkembangan sindrom metabolik.

Penelitian ini menjelaskan selain jumlah responden lebih banyak tidak memiliki riwayat penyakit lain, juga menjelaskan bahwa sebagian besar responden mempunyai riwayat penyakit lain yang tidak berakibat langsung terhadap lamanya penyembuhan luka ganggren, seperti penyakit pembuluh darah perifer / makro dan mikro angiopati.

\section{SIMPULAN}

1. Proses penyembuhan ulkus diabetikum pada umur $>55$ tahun 
mengalami proses penyembuhan lebih lama dibandingkan dengan usia $<55$ tahun.

2. Lama proses penyembuhan luka ganggre dipegaruhi oleh stadium luka, dimana pada stadium luka 3 \& 4 didapatkan hari rawat tidak normal / hari penyembuhan luka lebih lama daripada luka pada stadium $1 \& 2$.

3. Nilai Gula Darah Sewaktu (GDS) menjadi faktor yang didapatkan pada penelitian ini. Pada responden dengan nilai pemeriksaan GDS tidak normal, didapatkan waktu penyembuhan lebih panjang dari responden dengan nilai pemeriksaan GDS normal.

4. Faktor berat dan ringannya luka berpengaruh terhadap lama penyembuhan. Semakin berat luka yang dialami pada responden dengan Diabetes Mellitus, maka akan semakin memperpanjang lama penyembuhan luka.

5. Satu faktor yang ditemukan pada penelitian ini yang tidak mempengaruhi lama dari penyembuhan adalah faktor riwayat penyakit lain.

\section{UCAPAN TERIMA KASIH}

Puji dan syukur penulis panjatkan kepada Tuhan Yang Maha Esa atas berkat dan rahmat-Nyalah sehingga penulis dapat menyelesaikan penelitian yang berjudul "Faktor Yang Mempengaruhi Lama Penyembuhan Ganggren Pasien Diabetes Mellitus Di Klinik Alfacare Tahun 2019" dengan baik.

Pada kesempatan ini, penulis hendak menyampaikan terima kasih kepada semua pihak dari Poltekkes Kemenkes Bengkulu yang telah memberikan dukungan moril maupun materiil sehingga penelitian ini dapat selesai. Penulis menyadari bahwa penelitian ini masih ada kekurangan. Oleh karena itu, penulis mengharapkan kritik dan saran yang membangun dari para pembaca guna menyempurnakan segala kekurangan dalam penyusunan penelitian ini.

\section{DAFTAR PUSTAKA}

Adi, O. (2010). Prevalensi Diabetes Melitus dan Faktor-Faktor yang Berkaitan Dikalangan Penduduk. Buletin Kesehatan Masyarakat. Surabaya: Sastra Media.

ADA (American Diabetes Association). (2010). Diagnosis and Classification of Diabetes Mellitus. Diabetes Care Vol.33: S62-9.

American Diabetes Association. (2005).

Diabetes Management in Correctional Institutions. Diabetes Care, 28(suppl 1), s53 LP-s60. 
https://doi.org/10.2337/diacare.28.s uppl 1.S53

Arisanty, I. P. (2013). Manajemen Perawatan Luka. Jakarta: Konsep Dasar.

Hastuti, R. T. (2008). Pada Penderita Diabetes Mellitus (Studi Kasus di RSUD Dr. Moewardi Surakarta). Tesis.

Hess, C.T. (2002). Clinical Guide WoundCare, 4thEd. Pensylvenia: Springhouse.

Ismayanti. (2007). Luka Gangren pada Diabetik. http://ismadiary. blogspot.com/2007/02/lukagangrene-pada-diabetik.html

King, P., Peacock, I., \& Donnelly, R. (1999). UKPDS: clinical and therpeutic implications for DM2. British Journal of Clinical Pharmacology, 1-6. https://doi.org/10.1046/j.13652125.1999.00092.x

Lestari, Tri Suci. (2012). Hubungan Psikososial dan Penyuluhan Gizi dengan Kepatuhan Diet Pasien Diabetes Mellitus Tipe 2 Rawat Jalan di RSUP Fatmawati Tahun 2012. Skripsi. Universitas Indonesia, Depok.

MJ Lede, dkk. (2018). Pengaruh Kadar Gula Darah Terhadap Penyembhan Luka Diabetes Mellitus Di Puskesmas Dinoyo Malang. Nursing News Volume 3, Nomor 1, 2018. 3, 539-549.

Noer,Sjaifoellah. (2009). Buku Ajar Ilmu Penyakit Dalam jilid 2.Jakarta: FKUI
Nugroho \&Wahyudi. (2008). Keperawatan gerontik \& geriatri. Jakarta: EGC.

Rahmadiliyani, N., Muhlisin, A. (2008). Komplikasi Pada Penderita Diabetes Melitus Dengan Di Wilayah Kerja Puskesmas. I Gatak Sukoharjo, 63-68.

Syamsuhidayat, R.\& Jong, W.D.(2010).Buku Ajar Ilmu Bedah. Jakarta:EGC

Smeltzer \& Bare . (2008). Textbook of Medical Surgical Nursing Vol.2. Philadelphia: Linppincott William \& Wilkins.

Soegondo S. (2013). Prinsip dan Strategi Edukasi Diabetes. Dalam: Soegondo S, dkk, Penatalaksanaan Diabetes Mellitus Terpadu. Jakarta: Balai Penerbit FKUI

WHO. World Health Statistic Report. (2000). Geneva: World HealthOrganization

Yunus, Bahri. (2015). Faktor-faktor yang Mempengaruhi Lama Penyembuhan Luka pada Ulkus Diabetikum Di Rumah Perawatan ETN Centre Makassar. Skripsi. Fakultas Kedokteran dan Ilmu Kesehatan UIN Alaudin Makassar. 